\title{
A Qualitative Study on Role of Self Help Group In Tribal Women Empowerment In Rayagada Block Of Gajapati District Of Odisha,India
}

\author{
Sumita Acharya*,Dr.Puspanjali Samantray** \\ *Subject Matter Specialist,Krishi Vigyan Kendra,Angul,Odisha \\ **Professor,Department of Home Science,Berhampur University,Odisha
}

\begin{abstract}
Background: Women empowerment is an essential precondition for elimination of poverty. Many International and National bodies have stressed on women empowerment giving attention to their participation in society, decision-making, education and health. In India, Self Help Group intervention has brought tremendous change in the life of women at the grass root level. Currently around 50 SHGs exist in Rayagada block of Gajapati district of Odisha and are successfully managed by women.

Aim: To assess the role of Self-Help Groups in empowerment of tribal women of rural of Rayagada block. Methodology: It was a community based qualitatively study. Ten SHG groups were selected on feasibility basis. The SHG members' perception of improvement in different pre determined domains were assessed. Content analysis was done manually and the key findings were noted.

Results: The key responses were 'increased participation in household decision making', 'gaining respect in family', 'increased savings', 'meeting family expenses', 'improved political knowledge', 'independence', 'confidence' etc. They said to have gained respect and trust in society and were able to plan for the future of their families. Conclusions: Self Help Groups played very important role in Women empowerment and should be promoted for economic development of the country.
\end{abstract}

Keywords: Self-help Group, Empowerment, Participation, Decision making

\section{Introduction}

Poverty around the globe, about $70 \%$ is women. For these women, poverty doesn't just a life of dignity is the right of every citizen and mean scarcity and want, rather, rights denied, poverty is an obstruction to a dignified life.

1. The 1.3 billion people who live in absolute Women, who represent half of the human resource are often not recognized and regarded so, due to their inferior positioning in the society. According to the reports of the United Nations Millennium Campaign to halve world poverty by the year 2015, women make up two- thirds of the adults worldwide who cannot read or write, work two-thirds of the world's working hours, earn only 10 percent of the world's income and own less than 1 percent of the world's property.

2 Women are the poorest of the poor, thus women empowerment is a matter of basic human rights. Hence, International Conference on Population and Development (ICPD) held at Cairo 1994, called attention to women's empowerment as a central focus and declared that if human development is not engendered, it is endangered.

3 Considering all these factors, women empowerment is inevitable for the overall progress of community and the country which is also stressed in Millennium Development Goals (MDG - 3) (to promote gender equality and empower women). 'Empowerment' is a continuous process by which powerless people become conscious of their situation, organize collectively to improve it and access opportunities, as an outcome of which they take control over their own lives, set their own agenda, gain skills, solve problems and develop self-reliance.

4 In India, Self Help Group (SHG) intervention has brought tremendous change in the life of women at the grass root level by empowering women. The first organized initiative in this regard was taken in Gujarat in 1954 and was given a more systematized structure in 1972, when Self Employed Women's Association (SEWA) was formed. Major experiments in small group formation (SHGs) and its linkage to the bank for credit delivery at the local level were initiated in Tamil Nadu and Kerala about two decades back. These initiatives gave a firm footing to SHG movement in these States.

5 Self-help groups area small voluntary association of poor and the marginalized people preferably from the same socio-economic background which has actually become the vehicle of change for the poor and marginalized people to be released from the clutches of poverty. Though there are many SHGs in Gajapati districts and most of them are managed by women, yet the information about empowerment especially from the 
rural area is lacking. Thus this study was planned with the objective to assess women's perception about the role of SHGs in improving their situation (empowerment) in rural Rayagada block of Gajapati district of Odisha.

\section{Methodology}

A Qualitative study design was adopted to explore the women's perceptions of their improvement in different domains. These domains were our major parameters for the study; freedom of mobility, ability to make purchases, household decisions, political awareness, economic security, freedom from domination etc. Before conducting the main study, a preliminary meeting was held with a nongovernmental organization, concerned with formation and capacity building of various self help groups in the adjoining villages of Rayagada block. Preliminary Focus Group Discussions (FGD) were conducted among two SHG group members to have background knowledge about their functioning and to assess the feasibility of the key domains to be explored. Thus, for the main study, a total of 10 SHGs were selected from Rayagada block, the village adjoining our Institute, based on feasibility. About six FGDs were conducted (one each) among the group members of the SHGs and their perception of improvement in different domains (before and after joining SHG) was obtained being moderated by the principal investigator. Field notes were taken by the trained note takers and were also substantiated by audio recordings. At the end of FGD, participants were also explained to depict their group's perception (group consensus) before and after joining SHGs for all the domains on chart in the form of spider diagrams. It was graded from zero to five in each of the five arms of the spider diagrams; zero being the worst and five being the best condition. It was well explained to them and the corresponding area covered before and after joining the SHG was plotted for visual representation. Manual Content analysis was done and themes were generated.

\section{Freedom of Mobility}

\section{Results}

The findings of our study were broadly categorized into nine domains. These were before joining SHG; women were depending entirely on their family members for outward activities. After joining the SHG, they perceive to have more freedom of mobility and were able to manage most of the out-door activities (taking children to school, doing daily house hold purchase etc.) without any hindrance from family members. They were able to go to hospitals, banks and even to distant places independently. As mentioned by a participant, "Previously; my husband used to drop me whenever I had to go to any relative's house, because I didn't know how to go. Now I can manage alone".

\section{Freedom from domination}

Relative freedom from domination by the family all the group members invariably experienced a change in the attitude of their husbands and other family members and felt relatively relaxed from domination after joining SHG. They said that previously, they were ill-treated, verbally abused and were even beaten by their husbands but after joining SHG, they were treated with respect in their families. Few women said that they could voice against any ill treatment from family on them. As said by them, "Now they (family members) are not treating us badly. We also help in the family's financial assistance as we have become part of the family income"

\section{Involvement in decision making}

Involvement in decision making almost all the group members opined that their involvement in decision making in family had been improved. Contrary to what was happening before, after they started earning, they were even consulted by their husbands before taking any decisions on matters like house hold expenses, buying TV or other items, children's education etc. Even before starting a new business, their opinion was sought for which gave them a feeling of importance and well being. However, some women felt that they had developed independent decision making and even had the courage to take it against their family members if they felt it as good. As said by a group member, "Both of my kids are girls. Initially, no one in family agreed for sterilization because they wanted a son. But, I decided to undergo sterilization without intimating them".

\section{Purchasing ability}

Ability to make small and large purchases of the women had undoubtedly increased after joining SHG. Almost all the members who are earning in group were independently purchasing necessary household and personal things. As commented by a participant, "As I was jobless, had no money and felt bad when my children asked me some minor things like chocolate etc, but now the things are completely different after joining SHG" 


\section{Meeting family expenses}

After joining SHG, the women were able to spend money to meet family requirements like paying house rent, children's fee, medical expenses, household items etc. They were even able to manage regular savings by deciding on priorities heads of expenses. Thus, at times of need, they could contribute to important events like marriage, education, constructing houses etc. from the savings which improved their status and respect in families. They were also getting better co-operation and support from family for participating in SHG activities. As stated by a participant, "Previously my husband used to shout if I have not cooked in time, but now, he adjusts if some day, I am late due to group meetings".

\section{Economic security}

Many members said to have opened savings accounts in bank or post office after joining SHG and were having regular savings. Thus, they were able to avail loan against their savings and utilized in various income generating activities like making incense sticks, retail shop, dairy, transport business etc either in group or individually. Some members invested money in making new house or in gold as they thought that these were profitable investments for long term. They were also able to make useful expenses which were difficult for them to do before, because of financial crisis in family. As said, "I started my own business with the help of SHG and my monetary crisis was almost over. I could avail higher studies for my daughter; I spend my maximum savings for her education".

\section{Political and legal awareness}

After joining SHG, the members' level of awareness in political, educational and legal fields had increased. They were well informed about their local leaders and some knowledge about the Nation's political affairs. They even knew the legal age of marriage for boys and girls, dates of election as well as the nominated candidates.

Table -1. Income of the family of the respondents of Rayagada Block (Before and After Joining)

\begin{tabular}{|l|c|c|c|c|c|}
\hline \multirow{2}{*}{} & \multirow{2}{*}{ Score } & \multicolumn{2}{|c|}{ Before } & \multicolumn{2}{c|}{ After } \\
\cline { 3 - 6 } & & No & $\%$ age & No & $\%$ age \\
\hline Low & 1 & 13 & 26 & 4 & 8 \\
\hline $\begin{array}{l}\text { Semi- } \\
\text { Medium }\end{array}$ & 2 & 24 & 48 & 23 & 46 \\
\hline Medium & 3 & 12 & 24 & 16 & 32 \\
\hline High & 4 & 1 & 2 & 7 & 14 \\
\hline Total & & $\mathbf{5 0}$ & $\mathbf{1 0 0}$ & $\mathbf{5 0}$ & $\mathbf{1 0 0}$ \\
\hline
\end{tabular}

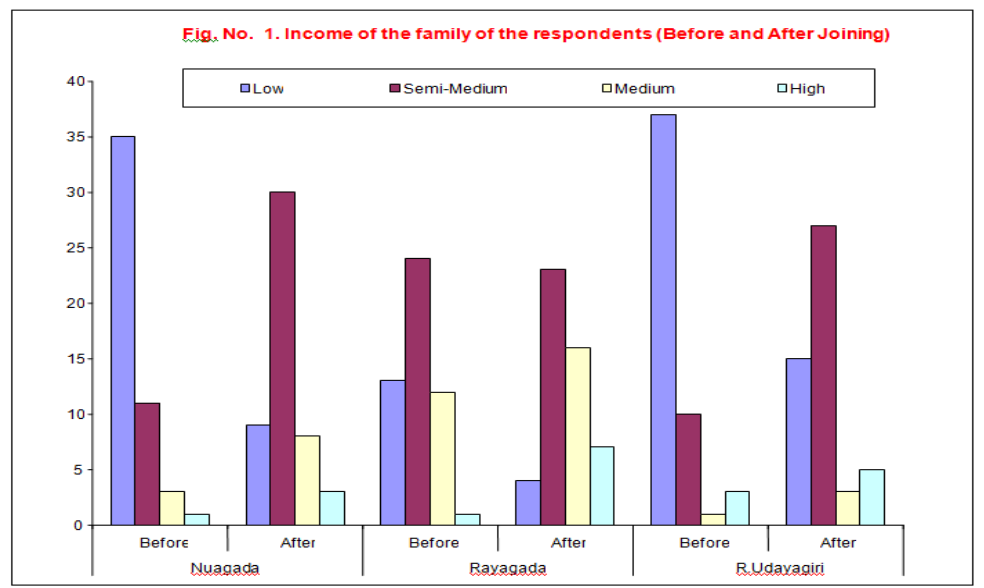


Table -2. CORRELATION OF DIFFERENT VARIABLES OF EMPOWERMENT (BEFORE RAYAGADA)

\begin{tabular}{|l|c|c|c|c|c|c|c|c|c|}
\hline & Education & $\begin{array}{c}\text { Land } \\
\text { Ownership }\end{array}$ & Oth.Asset & $\begin{array}{c}\text { C.Own } \\
\text { Inc }\end{array}$ & C.Fam.Inc & Assess.Cre. & Savings & Soc.Part & $\begin{array}{c}\text { Cash } \\
\text { income }\end{array}$ \\
\hline Education & 1.000 & & & & & & & & \\
\hline $\begin{array}{l}\text { Land } \\
\text { Ownership }\end{array}$ & 0.049 & 1.000 & & & & & & & \\
\hline Oth.Asset & 0.036 & -0.190 & 1.000 & & & & & & \\
\hline C.Own Inc & -0.048 & -0.044 & 0.059 & 1.000 & & & & & \\
\hline C.Fam.Inc & $0.286 *$ & 0.063 & 0.165 & 0.070 & 1.000 & & & & \\
\hline Assess.Cre. & 0.095 & -0.125 & 0.057 & -0.032 & 0.174 & 1.000 & & & \\
\hline Savings & -0.155 & 0.161 & -0.096 & 0.121 & -0.020 & -0.092 & 1.000 & & \\
\hline Soc.Part & -0.213 & -0.152 & -0.072 & -0.175 & -0.058 & 0.133 & 0.197 & 1.000 & \\
\hline $\begin{array}{l}\text { Cash } \\
\text { income }\end{array}$ & 0.066 & 0.097 & -0.116 & 0.066 & 0.035 & -0.002 & 0.165 & -0.066 & 1.000 \\
\hline
\end{tabular}

All other correlation values except star mark are Non Significant

Table -3. CORRELATION OF DIFFERENT VARIABLES OF EMPOWERMENT (AFTER RAYAGADA)

\begin{tabular}{|c|c|c|c|c|c|c|c|c|c|}
\hline & Education & $\begin{array}{c}\text { Land } \\
\text { Ownership }\end{array}$ & Oth.Asset & $\begin{array}{c}\text { C.Own } \\
\text { Inc }\end{array}$ & C.Fam.Inc & Assess.Cre. & Savings & Soc.Part & $\begin{array}{c}\text { Cash } \\
\text { income }\end{array}$ \\
\hline Education & 1.000 & & & & & & & & \\
\hline $\begin{array}{l}\text { Land } \\
\text { Ownership }\end{array}$ & 0.098 & 1.000 & & & & & & & \\
\hline Oth.Asset & -0.031 & -0.073 & 1.000 & & & & & & \\
\hline C.Own Inc & 0.181 & 0.014 & 0.024 & 1.000 & & & & & \\
\hline C.Fam.Inc & $0.378 * *$ & 0.014 & 0.174 & $0.554^{* *}$ & 1.000 & & & & \\
\hline Assess.Cre. & - & - & - & - & - & 1.000 & & & \\
\hline Savings & -0.140 & -0.004 & 0.203 & 0.100 & -0.163 & - & 1.000 & & \\
\hline Soc.Part & 0.157 & 0.018 & -0.184 & 0.141 & 0.068 & - & $-0.269 *$ & 1.000 & \\
\hline $\begin{array}{l}\text { Cash } \\
\text { income }\end{array}$ & 0.027 & $0.248^{*}$ & $0.303 *$ & 0.023 & 0.023 & - & 0.055 & -0.183 & 1.000 \\
\hline
\end{tabular}

All other correlation values except star mark are Non Significant

\section{Conclusion}

SHGs are the key instruments in women's empowerment which are generally facilitated and supported by NGOs. These NGOs advise and train members in a variety of on- and off-farm income-generating activities. In the present study also SHGs had played very important role in empowering women by strengthening their earning ability, boosting their self-confidence and promoting regular savings. Thus the participants had economic security, easy credit accessibility, better decision making in family, improved family environment (relative freedom from domination), increased mobility and improved political and legal knowledge. SHGs had provided women a common platform to discuss and solve their individual and community problems. Since this study was conducted on feasibility basis, samples from wider geographical areas could have given us a better picture of the rural Gajapati districts. We recommend that Women SHGs formation especially in marginalized community of rural area should be encouraged; capacity building of the members should be ensured. Govt. should provide interest free/subsidised loan to SHG to help them come out of poverty.

\section{References}

[1]. Shinde KH, Ingole PS. Women Empowerment through Self Help Group in India. Accessed March 12, 2012

[2]. Drinkwater M. 'We are also Human': Identity and Power in Gender Relations. November 27th, 2011.

[3]. Mostofa G, Tareque I, Haque M, Islam TM. Mathematical Modelling of Women Empowerment in Bangladesh. RJAS 2008;3(6):41620.

[4]. Kulkarni VS. International Fund for Agricultural Development. Women's Empowerment and Microfinance, An Asian Perspective Study. 2011. p1137.

[5]. Government of India, Second Administrative Reforms Commission- 9th Report, Third Sector Organisations at the Local Level Self-Help Group. 2008. p 68-112.

[6]. Zahir Hussain B. Impact of Self-Help Groups on Women Empowerment in the Union Territory of Pundicherry- A Case Study.

[7]. Cheston S, Kuhn L. Empowering Women through Microfinance. 2002.

[8]. MkNelly B, McCord M. Credit with Education on Women's Empowerment and Freedom from Hunger. Impact Review No. 1. 2001

[9]. Kabeer N. Money Can't Buy Me Love? Re-evaluating the Empowerment Potential of Loans to Women in Rural Bangladesh. 1998.

[10]. A Mid-Term Evaluation of Nirdhan, A Leading Microfinance Institution Nepal, and its Partnership Project with Plan InternationalNepal 2000.

[11]. Ashe J, Parroott L. PACT's Women's Empowerment Program in Nepal: A Savings and Literacy Led Alternative to Financial Building. Journal of Microfinance 2002;4(2):132-67. 